\title{
Energy supplementation in Santa Inês sheep subjected to estrus induction treatment
}

\section{Suplementação calórica em ovelhas da raça Santa Inês submetidas à indução do estro sincronizado}

\author{
Sabrina Silva Venturi ${ }^{1}$; Jeferson Ferreira da Fonseca ${ }^{2}$; Ana Clara Sarzedas Ribeiro ${ }^{3}$; \\ Marcos Cláudio Pinheiro Rogério ${ }^{4}$; Juliana de Oliveira ${ }^{5}$; Alexandre Ribeiro \\ Araújo $^{6}$; Joanna Maria Gonçalves Souza-Fabjan ${ }^{7}$; Felipe Zandonadi Brandão ${ }^{8 *}$
}

\begin{abstract}
The aim of this study was to evaluate the effect of a $20 \%$ increase in dietary energy during short-term estrus induction treatment on the reproductive parameters of Santa Inês ewes. Females $(n=43)$ were allocated into two experimental groups according to the amount of energy inclusion in the diet: maintenance diet or maintenance diet plus $20 \%$ energy. Ultrasound examinations were performed in order to detect ovulation. To assess sexual behavior, ewes were teased and further mated. Blood samples were collected for the determination of glucose and insulin concentrations. There was no difference $(\mathrm{P}>0.05)$ between groups in the following categories: ovulation rate $(80.00 \%$ vs. $60.00 \%)$, largest follicle diameter $(6.00 \pm 0.20 v s$. $5.90 \pm 0.60)$, interval from device removal to ovulation $(52.80 \pm 14.87 \mathrm{vs} .59 .01 \pm 8.34$ hours $)$, animals in estrus $(75.00 \%$ vs. $65.21 \%)$, interval from device removal to estrus $(30.00 \pm 15.49 v s .30 .00 \pm 13.35$ hours) and conception rate $(50.00 \%$ vs. $21.73 \%)$. There were differences $(\mathrm{P}<0.05)$ in the concentrations of insulin and glucose. It can be concluded that the $20 \%$ increase in energy in the diet during short-term estrus induction treatment did not affect the reproductive parameters studied.
\end{abstract}

Key words: Glucose, insulin, ovulation rate, sheep

\section{Resumo}

O objetivo deste estudo foi avaliar o efeito do aumento em $20 \%$ da energia da dieta durante um protocolo curto de sincronização do estro sobre os parâmetros reprodutivos e metabólicos em ovelhas da raça Santa Inês. As ovelhas ( $\mathrm{n}=43$ ) foram distribuídas em dois grupos experimentais de acordo com a quantidade de energia incluída na dieta, onde foram utilizadas uma dieta de manutenção e uma dieta de manutenção acrescida em $20 \%$ de energia. Exames ultrassonográficos foram realizados para detectar a ovulação, bem como o diâmetro dos folículos. Para avaliação do comportamento sexual as ovelhas foram rufiadas. Foram coletadas amostras de sangue para determinação das concentrações plasmáticas

${ }^{1}$ M.e, Discente do Programa de Pós-Graduação em Medicina Veterinária da Universidade Federal Fluminense, UFF, Niterói, RJ, Brasil. E-mail: sabrifoxvet@yahoo.com.br

2 Dr., Pesquisador, Embrapa Caprinos e Ovinos, Coronel Pacheco, MG, Brasil. E-mail: jeferson.fonseca@embrapa.br

${ }^{3}$ Discente, Faculdade de Veterinária, Universidade Federal Fluminense, UFF, Niterói, RJ, Brasil. E-mail: aninhahsarzedas@, hotmail.com

${ }^{4}$ Dr., Pesquisador da Embrapa Caprinos e Ovinos, Sobral, CE, Brasil. E-mail: marcosclaudio@gmail.com

5 Prof $^{\mathrm{a}}$ Dr $^{\mathrm{a}}$ Adjunto, UFF, Niterói, RJ, Brasil. E-mail: juliana.deoliveira@yahoo.com.br

${ }^{6}$ M.e, Discente do Programa de Pós-Graduação em Zootecnia, Universidade Federal de Minas Gerais, UFMG, Belo Horizonte, MG, Brasil. E-mail: alexandre.xandyzoo@gmail.com

${ }^{7}$ Dr ${ }^{\mathrm{a}}$, Pós-doutoranda do Programa de Pós-Graduação em Medicina Veterinária, UFF, Niterói, RJ, Brasil. E-mail: joannavet@ gmail.com

${ }^{8}$ Prof. Dr. Associado, Programa de Pós-Graduação em Medicina Veterinária, UFF, Niterói, RJ, Brasil. E-mail: fzbr@vm.uff.br

* Author for correspondence 
de glicose e insulina. Não houve diferença $(\mathrm{P}>0,05)$ entre os grupos para: taxa de animais ovulando ( $80 \%$ vs 60\%), diâmetro do maior folículo $(6,00 \pm 0,20$ vs 5,90 $\pm 0,60)$, intervalo da retirada do implante à ovulação $(52,80 \pm 14,87$ vs $59,01 \pm 8,34$ horas), animais em estro $(75,00 \%$ vs $65,21 \%)$, intervalo da retirada do implante ao estro $(30,00 \pm 15,49$ vs $30,00 \pm 13,35$ horas $)$ e taxa de concepção $(50,00 \%$ vs $21,73 \%)$. Houve diferença $(\mathrm{P}<0,05)$ nas concentrações de insulina e glicose. Pode-se concluir que o aumento em $20 \%$ da energia da dieta durante um protocolo curto de sincronização do estro não alterou os parâmetros reprodutivos.

Palavras-chave: Glicose, insulina, ovelha, taxa de ovulação

\section{Introduction}

The sheep population in Brazil is approximately 16,789 animals, and the Northeast and South regions together represent $85 \%$ of national sheep production (IBGE, 2012). The sheep industry was, until recently, seen as a secondary livestock activity, characteristic of less-developed regions; in recent years this industry has shown strong growth in exploration for economic purposes in all regions of the country (SIMPLÍCIO, 2011). Although there is still a very low ratio between the number of sheep and the number of people in Brazil, it is possible to see the great potential for its expansion (ANUÁRIO BRASILEIRO DE CAPRINOS E OVINOS, 2008).

Animal productivity is a result of genetic potential and the environment, and food is the most important factor in the environment. To enhance animal productivity, the availability of quality food is essential (VIDAL et al., 2006). When sanitary, nutritional and animal welfare conditions are adequately met, the production system will be limited by the efficiency of the reproduction rates. This efficiency can be increased with the use of assisted reproductive biotechnologies (FONSECA; BRUSCHI, 2005).

The knowledge of the endocrine mechanisms involved in the estrous cycle have allowed for the development of hormonal protocols, either alone or associated with management techniques, which allow for the control of the expression of estrus and ovulation in sheep. Conventional treatments of induction and synchronization of estrus involve the association of prostaglandins and intravaginal devices impregnated with progesterone or progestin in combination with equine chorionic gonadotropin
(eCG) (FONSECA; BRUSCHI, 2005; SOUZA, 2013). Estrus synchronization is a valuable tool that has been successfully used to increase reproductive efficiency, enabling producers to schedule the birth of lambs, plan nutritional management, form uniform lots and take advantage of the price trends of the market (SOUZA, 2013).

Food supplementation can be associated with efficient reproductive management. An increase in the level of nutrition before mating, known as flushing, is often practiced in the sheep industry to increase the ovulation rate. The effect of nutrition on ovulation rate is not promoted by a specific nutrient, hormone or metabolite, and this relationship has not been well demonstrated (ROBINSON et al., 2002). Nutrients involved in the production of pituitary hormones are directly responsible for maturation of the reproductive organs and increased prolificacy and ovulation rate and indirectly responsible for the improvement of the animal's body condition (SELAIVE-VILLARROEL et al., 2002; VIÑOLES et al., 2009).

Insulin and glucose concentrations are associated with the ovarian regulatory system, and glucose is the major source of energy in the ovary. Increased energy supply favors the development of follicles (MUÑOZGUTIÉRREZ et al., 2004, 2005; SCARAMUZZI et al., 2006; WILLIAMS et al., 2001).

According to Saunders et al. (2010), food supplementation can influence the ovulation rate by promoting greater hepatic metabolism of steroid hormones and, hence, a reduction of the negative feedback in the release of gonadotropins, follicle stimulating hormone $(\mathrm{FSH})$ and luteinizing hormone (LH). 
For many authors, the boost in energy intake determines the increase of insulin and insulin-like growth factor (IGF-I) in the blood, which act on the follicles in combination with FSH, stimulating folliculogenesis and thus increasing the ovulation rate (FORTUNE et al., 2004; SAUNDERS et al., 2010; SCARAMUZZI et al., 2006). This study aimed to evaluate the immediate effect of increasing energy by $20 \%$ in the diet on the reproductive and behavioral parameters and circulating concentrations of insulin and glucose in Santa Inês sheep.

\section{Materials and Methods}

This research was reviewed and approved by the Animal Care Committee of the Universidade Federal Fluminense (protocol 043/08) and was conducted from August to November of 2008 at Fazenda Jororó do Sertão, in Cachoeira de Macacu, RJ, Brazil. A total of 43 Santa Inês ewes previously selected by gynecological exam with an average body weight of $36.9 \pm 5.5 \mathrm{~kg}$ and body condition score of $2.8 \pm 0.3$ were used. For mating, six fertile Santa Inês rams were used, with a ram:ewe ratio of approximately 1:7.
The animals were maintained in a semi-intensive system and were outside during the day and inside during the night. The nutritional management before the start of the study was based on chopped Cameroon grass (Pennisetum purpureum), sugarcane and concentrate, as well as grazing pasture formed by Brachiaria sp. Mineralized salt and water were offered ad libitum.

Females were allocated according to their body weight and condition score into two groups: $\mathrm{G}_{M}-$ animals receiving the maintenance diet during the estrus induction protocol $(\mathrm{n}=20 ; 15$ pluriparous and 5 nulliparous) and $\mathrm{G}_{\mathrm{M}+20 \%}$ - animals receiving the maintenance $+20 \%$ energy diet during the same period ( $\mathrm{n}=23 ; 18$ pluriparous and 5 nulliparous).

In $\mathrm{G}_{\mathrm{M}}$, the maintenance diet was established according to NRC (2007) guidelines for crude protein (CP) and total digestible nutrients (TDN), categorizing adult sheep with an average body weight of $40 \mathrm{~kg}$ as maintenance only, without predicting weight gain. An increase of $20 \%$ in $\mathrm{CP}$ and TDN characterized the second experimental group $\left(\mathrm{G}_{\mathrm{M}+20 \%}\right)$. The centesimal and chemical-bromatological compositions $(\%)$ of the experimental diets are listed in Table 1.

Table 1. Centesimal and chemical-bromatological composition (\%) of the dry matter of the experimental diets.

\begin{tabular}{lcc}
\hline Centesimal composition & $\mathbf{G}_{\mathbf{M}}^{\dagger}$ & $\mathbf{G}_{\mathbf{M}+20 \%}$ \\
\hline Tifton Hay 85 & 63.96 & 48.31 \\
Malt & 32.38 & 11.34 \\
Corn & - & 36.45 \\
Wheat Bran & 3.00 & 3.19 \\
Megalac & 0.53 & 0.70 \\
Dicalcium Phosphate & 0.13 & - \\
\hline Chemical-bromatological composition & $\mathbf{G}_{\mathbf{M}}^{\dagger}$ & $\mathbf{G}_{\mathbf{M}+20 \%}$ \\
\hline Dry Matter & 91.00 & 90.49 \\
Crude Protein & 7.27 & 8.73 \\
Total Digestible Nutrients & 53.25 & 63.90 \\
Neutral Detergent Fiber & 62.37 & 46.17 \\
Calcium & 0.60 & 0.40 \\
Phosphorus & 0.17 & 0.20 \\
Ethereal Extract & $2.041 \%$ & $3.154 \%$ \\
\hline
\end{tabular}

${ }^{\dagger} \mathrm{G}_{\mathrm{M}}=$ Maintenance diet; $\mathrm{G}_{\mathrm{M}+20 \%}=$ Maintenance diet $+20 \%$ of crude protein and total digestible nutrients. 
The females were allocated into six pens according to experimental treatment and body weight to prevent competition for food among animals. The total amount of concentrate and hay offered daily were calculated based on the average weight of the animals in each pen.

For estrus induction, a progesterone-releasing device containing $0.3 \mathrm{~g}$ progesterone (EaziBreed CIDR ${ }^{\mathrm{o}}$, Pfizer Animal Health, Brazil) was maintained for six days, and $24 \mathrm{~h}$ before its removal, 300 IU equine chorionic gonadotropin (Novormon ${ }^{\circ}$, Syntex, Buenos Aires, Argentina) and $12.5 \mathrm{mg}$ dinoprost (Lutalyse ${ }^{\mathrm{o}}$, Pfizer Animal Health, Brazil) were administered i.m.

Transrectal ovarian ultrasonography was performed by the same operator every $12 \mathrm{~h}$ after device removal until the detection of ovulation to determine the time and number of ovulations as well as the diameter of pre-ovulatory follicles. All examinations were conducted with a B-mode transrectal ultrasonographic scanner with a $5 \mathrm{MHz}$ transducer (Aloka SSD 500 ${ }^{\circledR}$, Tokyo, Japan). To facilitate manipulation of the transducer, it was taped to a PVC tube. Ewes were maintained in a standing position, fecal pellets were removed manually (with a finger), and $20 \mathrm{~mL}$ of carboxymethylcellulose gel was placed into the rectum with a syringe. Ovaries were located using as reference the urinary bladder and uterus, and the number, diameter, and position of ovarian follicles $\geq 3 \mathrm{~mm}$ was recorded. After device removal, estrus was monitored with the use of teaser rams, and females in estrus were mated by fertile rams. Approximately $30 \mathrm{~d}$ after breeding, the same equipment was used to conduct ultrasonographic pregnancy diagnosis for all 43 ewes.

Blood samples for glucose and insulin analysis were collected by jugular venipuncture in 20 ewes (10 per group) in the morning after fasting for $12 \mathrm{~h}$. Blood collection was performed at the following times: the start of the adaptation period to nutritional management (T0); onset of estrus induction treatment and start of diets, permanence of the maintenance diet in $\mathrm{G}_{\mathrm{M}}$ and the start of the flushing diet in $\mathrm{G}_{\mathrm{M}+20 \%}$ (T1); administration of eCG and PGF2 $\alpha$ (T2) and estrus onset (T3). Sodium fluoride was added to each sample after collection. Then, the samples were centrifuged and stored at $-20{ }^{\circ} \mathrm{C}$ for further analysis. Glucose analysis was performed by the use of a commercial kit (Glicose Liqiform, LabTest Diagnostic SA ${ }^{\circledR}$, Lagoa Santa, Brazil), and insulin level was determined by a commercial solid phase radioimmunoassay (RIA) kit (Coat-a-Count ${ }^{\circledR}$, Medlab), used according to the manufacturer's instructions.

Qualitative variables were analyzed a by chisquare test, whereas quantitative variables were submitted to a Tukey or Duncan test. A value of $\mathrm{P}<0.05$ was considered to be significant. Statistical analyses were performed using SAS software.

\section{Results and Discussion}

Nutritional treatment did not affect $(\mathrm{P}>0.05)$ ewes' body weights at the different timepoints evaluated (Table 2), making it possible to evaluate the immediate effect of nutrition on circulating metabolites. Therefore, it may be affirmed that body weight did not affect the parameters evaluated.

The ovulation rate, number of ovulations, preovulatory follicle diameters and the interval from device removal to ovulation were similar $(\mathrm{P}>0.05)$ for both treatments (Table 3). Several authors (FINDLAY; CUMMING, 1976; KNIGHT, 1980; RADFORD et al., 1980; SMITH; STEWART, 1990) reported that nutritional treatments promote an increased ovulation rate, which was not observed in this study, where supplementation for six days did not increase the ovulation rate in comparison with the control group. 
Table 2. Body weight $(\mathrm{kg})$ of Santa Inês ewes that received the maintenance diet $\left(\mathrm{G}_{\mathrm{M}}\right)$ or the $20 \%$ more energy diet $\left(\mathrm{G}_{\mathrm{M}+20 \%}\right)$ during estrus induction treatment (mean $\left.\pm \mathrm{SD}\right)$.

\begin{tabular}{cccc}
\hline & \multicolumn{3}{c}{ Body weight (kg) } \\
\cline { 2 - 4 } & $\mathbf{G}_{\mathbf{M}}$ & $\mathbf{G}_{\mathbf{M}+20 \%}$ & Mean \\
\hline T0 & $36.57 \pm 5.56(20)$ & $37.24 \pm 5.45(23)$ & $36.88 \pm 5.46(43)$ \\
T1 & $36.61 \pm 5.68(20)$ & $35.99 \pm 5.09(23)$ & $36.32 \pm 5.36(43)$ \\
T3 & $36.44 \pm 5.42(20)$ & $36.31 \pm 5.04(23)$ & $36.38 \pm 5.19(43)$ \\
\hline Mean & $36.54 \pm 5.47(60)$ & $36.51 \pm 5.14(69)$ & $36.53 \pm 5.30(129)$ \\
\hline
\end{tabular}

Times: T0 - start of adaptation period to nutritional management; T1 - onset of estrous induction treatment and start of diets; and T3 - estrous onset. Values between parentheses refer to the number of animals. $\mathrm{P}>0.05$.

Table 3. Ovulation rate (\%), number of ovulations per ewe, diameter of the largest follicle and interval from device removal to ovulation in Santa Inês ewes that received the maintenance $\operatorname{diet}\left(\mathrm{G}_{\mathrm{M}}\right)$ or the $20 \%$ more energy $\operatorname{diet}\left(\mathrm{G}_{\mathrm{M}+20 \%}\right)$ during estrus induction treatment (mean $\pm \mathrm{SD}$ ).

\begin{tabular}{lcc}
\hline Experimental groups & $\mathbf{G}_{\mathbf{M}}$ & $\mathbf{G}_{\mathbf{M}+20 \%}$ \\
\hline Ovulation rate (\%) & $60.00(6 / 10)$ & $80.00(8 / 10)$ \\
Number of ovulations & $1.00(6)$ & $1.13(8)$ \\
Diameter of largest follicle (mm) & $6.00 \pm 0.20(6)$ & $5.90 \pm 0.60(8)$ \\
Interval from device removal to ovulation (h) & $52.80 \pm 14.87(6)$ & $59.01 \pm 8.34(8)$ \\
\hline
\end{tabular}

Values between parentheses refer to the number of animals. $\mathrm{P}>0.05$, according to the Duncan test.

In another study, supplementation with lupins (Lupinus angustifolius), an energetic supplement, for a period similar to the current study led to an increase of $15 \%$ in ovulation rate, with no effect on body weight or body condition score (VIÑOLES, 2003). The same group of researchers (VIÑOLES et al., 2009) observed an increase of $12 \%$ in ovulation and prolificacy rate when using other legumes (Lotus corniculatus), in comparison with other animals fed only on native pasture. In the current study, it may be suggested that the increase in energy in the diet was not enough to affect this parameter.

Nutritional treatment usually promotes an increase in ovulation rate, since it particularly affects the gonadotropin-dependent (FSH) stage of follicular growth. Some researchers believe that the effect of nutrition on the hypothalamic-pituitarygonadal axis is not related to changes in circulating concentrations of FSH but to the follicle's sensibility to FSH action due to alterations in the hormonal feedback system (FINDLAY; CUMMING, 1976; KNIGHT, 1980; RADFORD et al., 1980).
Even though a discrepant increase in follicular growth and ovulation rate not observed in the current study, it is well known that an increase in insulin concentrations leads to an increased supply of glucose to the follicles, promoting a more rapidly growth of theca and granulosa cells, anticipating ovulation and increasing the ovulation rate (WILLIAMS et al., 2001).

Oldham and Lindsay (1984) reported that the supplementation period may be reduced to 6 days before mating. Stewart and Oldham (1986) evaluated periods of nutritional supplementation ( 4 to 8 days before ovulation) between the $10^{\text {th }}$ and the $14^{\text {th }}$ day of the cycle for sheep. They observed that the periods from 5 to 8 days led to an increased ovulation rate; however, this was not observed when the supplementation was performed only 1 or 4 days before mating. In the current study, applying the supplementation for 6 days before mating resulted in an increase in hormonal metabolites, but no effects in reproductive parameters were observed. 
Viñoles et al. (2005), who evaluating flushing diets (70\% Trifolium alexandrinum - annual clover and $30 \%$ concentrate $-80 \%$ hay and $20 \%$ soybean meal) in sheep for six days, from the $9^{\text {th }}$ to the $14^{\text {th }}$ day of the estrous cycle, did not observe an increase in the number of ovulations (both groups: $1.1 \pm 0.3$ ). The present study corroborates this finding, in which presumably the increase in diet energy level caused no hormonal changes, so supplementation was not sufficient to enhance the number of ovulations per ewe. Recently, it was shown that the pattern of LH secretion and sheep ovarian response was influenced by body condition, but not after shortterm nutritional supplementation (SCARAMUZZI et al., 2014).

The diameters of the largest follicle were $6.0 \pm$ $0.2\left(\mathrm{G}_{\mathrm{M}}\right)$ and $5.9 \pm 0.6\left(\mathrm{G}_{\mathrm{M}+20 \%}\right)$, with no difference between them. The results of the present study are in accordance with Ginther et al. (1995), Bartlewski et al. (1999) and Evans (2003), who they reported that the average diameter of pre-ovulatory follicles in ewes is approximately 5 to $7 \mathrm{~mm}$.

The observation that the follicle diameter at ovulation was not affected by the diet allowed us to affirm that both experimental groups had the same growth rate, i.e., LH and FSH acted similarly during follicle development. Smith and Stewart (1990) reported that animals showing an increased food intake rate had an increase in hepatic metabolism of steroid hormones, resulting in a reduction of negative feedback of these hormones on gonadotropin release. Adams et al. (1997) reported that the increase in nutrition determines the increase of estradiol clearance in the liver; thus, ewes fed with an energetic diet had circulating concentrations of estradiol $10 \%$ lower in comparison with those ewes receiving non-energetic diets, allowing forf the increase of FSH concentration.

We may suppose that the $20 \%$ energy increase in the diet in this study was not able to affect the hepatic metabolism of steroid hormones (estrogen and progesterone) and the release of gonadotropins (LH and FSH), promoting no difference in the pattern of follicular growth and the responses studied (ovulation rate, diameter of the preovulatory follicle at the time of ovulation).

No differences $(\mathrm{P}>0.05)$ were observed in the interval from device removal to ovulation for both groups (Table 4). Cline et al. (2001) used a device containing $3 \mathrm{mg}$ norgestomet combined with $400 \mathrm{IU}$ eCG for 10 days and reported an interval of 75.6 hours (range 60-96 hours). Cardwell et al. (1998) used the same device associated with $500 \mathrm{IU}$ eCG and reported an average interval of 68.6 hours. These intervals were higher than those found in our experiment, but different protocols for induction and synchronization of estrus were used. In a previous study using the same device, the same dose of eCG and the same breed, Cavalcanti et al. (2012) observed an interval from removal to ovulation of $59.0 \pm 3.5$ hours, similar to that found in this study.

As written above, there was no difference in the follicle diameter at the time of ovulation, so the rate of follicle growth in the two groups was similar. Therefore, it was not expected to identify differences in the time of ovulation in relation to the time of device removal. It is important to highlight this fact in order to identify whether this interval is essential for establishing the appropriate time for timed artificial insemination. 
Table 4. Percentage of Santa Inês ewes in estrus that received the maintenance diet $\left(\mathrm{G}_{\mathrm{M}}\right)$ or the $20 \%$ more energy diet $\left(\mathrm{G}_{\mathrm{M}+20 \%}\right)$ during estrus induction treatment (mean $\left.\pm \mathrm{SD}\right)$.

\begin{tabular}{lcc}
\hline Experimental groups & $\mathrm{G}_{\mathrm{M}}$ & $\mathrm{G}_{\mathrm{M}+20 \%}$ \\
\hline Estrous response rate (\%) & $75.00(15 / 20)$ & $65.21(15 / 23)$ \\
Interval from device removal to estrus* (h) & $30.00 \pm 15.49(15)$ & $30.00 \pm 13.35(15)$ \\
Conception rate** $\mathbf{( \% )}$ & $50.00 \% \%^{\mathrm{a}}(10 / 20)$ & $21.73 \% \%^{\mathrm{b}}(5 / 23)$ \\
\hline
\end{tabular}

Values between parentheses refer to the number of animals. $\mathrm{P}>0.05$, according to the $*$ Duncan test or $* *$ chi-square test.

A total of $69.76 \%$ of animals showed estrus (Table 3). The results obtained were similar to those found by other authors (CAVALCANTI et al., 2012; PINNA et al., 2012). Thus, $\mathrm{P}_{4}$ concentrations during the hormonal treatment were not affected by the diet and, hence, were enough to sensitize the central nervous system for animals to respond to the increase in circulating concentrations of estradiol, showing estrus.

Even though the ewes from $\mathrm{G}_{M}$ had a two times greater pregnancy rate than $\mathrm{G}_{\mathrm{M}+20 \%}$, no significant differences were detected. This fact is possibly explained by the low number of animals in each group, allowing for the overlap of confidence intervals, yielding results that are statistically equivalent (SAMPAIO et al., 1998).

After energy supplementation, an increase in plasma glucose in the animals is expected. It is known that glucose is a major energy carrier in the ovary (RABIEE et al., 1997). Such an increase would cause an increased insulin and glucose influx into the cell, resulting in glycolysis. It was noted in this study that increased energy was able to increase circulating insulin concentrations, followed by the increase in glucose after T1, regardless of treatment (Table 5). However, these results were not sufficient to affect the reproductive parameters.

Table 5. Circulating insulin ( $\mathrm{ng} / \mathrm{dl})$ and glucose $(\mathrm{mg} / \mathrm{dl})$ concentrations in Santa Inês ewes that received the maintenance $\operatorname{diet}\left(\mathrm{G}_{\mathrm{M}}\right)$ or the $20 \%$ more energy diet $\left(\mathrm{G}_{\mathrm{M}+20 \%}\right)$ during estrus induction treatment (mean $\pm \mathrm{SD}$ ).

\begin{tabular}{lcccc}
\hline Parameters & & $\mathbf{G}_{\mathbf{M}}$ & $\mathbf{G}_{\mathbf{M}+20 \%}$ & Mean time \\
\hline \multirow{4}{*}{ Insulin (ng/d) } & T0 & $1.24 \pm 0.90(10)$ & $3.08 \pm 4.28(10)$ & $2.16 \pm 3.15(20)$ \\
& T1 & $2.63 \pm 2.07(10)$ & $4.65 \pm 5.24(10)$ & $3.64 \pm 4.02(20)$ \\
& T2 & $1.11 \pm 1.19(10)$ & $2.08 \pm 1.92(10)$ & $1.59 \pm 1.64(20)$ \\
& T3 & $1.67 \pm 1.30(10)$ & $2.37 \pm 2.06(10)$ & $2.02 \pm 1.72(20)$ \\
\cline { 2 - 5 } & Mean & $1.66 \pm 1.51^{\mathrm{b}}(40)$ & $3.04 \pm 3.66^{\mathrm{a}}(40)$ & $2.35 \pm 2.87(80)$ \\
\hline \multirow{3}{*}{ Glucose (mg/ } & T0 & $50.70 \pm 6.91(10)$ & $52.35 \pm 9.03(10)$ & $51.52 \pm 7.87^{\mathrm{C}}(20)$ \\
dl) & T1 & $62.20 \pm 8.60(10)$ & $57.80 \pm 8.46(10)$ & $60.00 \pm 8.60^{\mathrm{B}, \mathrm{C}}(20)$ \\
& T2 & $74.05 \pm 15.14(10)$ & $71.05 \pm 6.72(10)$ & $72.55 \pm 11.50^{\mathrm{A}}(20)$ \\
& $\mathbf{T 3}$ & $70.20 \pm 7.72(10)$ & $69.70 \pm 25.46(10)$ & $69.95 \pm 18.31^{\mathrm{A}, \mathrm{B}}(20)$ \\
\cline { 2 - 5 } & Mean & $64.29 \pm 13.29(40)$ & $62.72 \pm 16.11(40)$ & $63.51 \pm 14.69(80)$ \\
\hline
\end{tabular}

Times: T0 - start of adaptation period to nutritional management; T1 - onset of estrous induction treatment and start of diets; T2 -administration of eCG and PGF2 $\alpha$ and T3 - estrous onset. Values between parentheses refer to the number of animals.

${ }^{\mathrm{a}, \mathrm{b}}$ Differed in the same row and ${ }^{\mathrm{A}, \mathrm{B}}$ differed in the same column, according to the Tukey test $(\mathrm{P}<0.05)$. 
The administration of glucose intravenously for five days (between the $8^{\text {th }}$ and $10^{\text {th }}$ day of the estrous cycle) determined an increase in circulating concentrations of insulin $(2.7 \pm 0.1$ vs. $2.4 \pm 0.1 \mathrm{ng} /$ ml) (DOWNING et al., 1995). Viñoles et al. (2005) also observed an increase in insulin concentrations on the $9^{\text {th }}, 11^{\text {th }}$ and $14^{\text {th }}$ day of the estrous cycle, after a short period of supplementation. In this study, we observed an increase in circulating insulin in the $\mathrm{G}_{\mathrm{M}+20 \%}$ treatment, even though this increase did not affect ovulation rate. This fact could be explained by the lower concentration of energy used in $\mathrm{G}_{\mathrm{M}+20 \%}$ in comparison with that used by Viñoles (2003). Viñoles (2003) tested the hypothesis that insulin and glucose concentrations are higher in sheep supplemented for a short period of time. They observed increased glucose on the $11^{\text {th }}$ day of the estrous cycle and increased insulin on the $9^{\text {th }}, 11^{\text {th }}$ and $14^{\text {th }}$ day of the estrous cycle $(\mathrm{P}<0.001)$.

The results of this study allow us to conclude that an increase of $20 \%$ energy in the diet of Santa Inês ewes for a short period of time during estrus induction treatment was not enough to promote benefits in the reproductive parameters evaluated.

\section{Acknowledgments}

The authors thank the Universidade Federal Fluminense - Proppi and FAPERJ for funding the project. FZB, MCPR and JFF are fellows of the CNPq and JMGSF of CAPES.

\section{References}

ADAMS, N. R.; BRIEGEL, J. R.; SANDERS, M. R.; BLACKBERRY, M. A.; MARTIN, G. B. Level of nutrition modulates the dynamics of oestradiol feedback on plasma FSH in ovariectomized ewes. Animal Reproduction Science, Manchester, v. 47, n. 1-2, p. 5970, 1997.

ANUÁRIO BRASILEIRO DE CAPRINOS E OVINOS. Uberaba: Editora Agropecuária Tropical Ltda., 2008. 194 p.
BARTLEWSKI, P. M.; BEARD, A. P.; COOK, S. J.; CHANDOLIA, R. K.; HONARAMOOZ, A.; RAWLINGS, N. C. Ovarian antral follicular dynamics and their relationships with endocrine variables throughout the oestrous cycle in breeds of sheep differing in prolificacy. Journal of Reproduction and Fertility, Cambridge, v. 115, n. 1, p. 111-124, 1999.

CARDWELL, B. E.; FITCH, G. Q.; GEISERT, R. D. Ultrasonic evaluation for 90 the time of ovulation in ewes treated with norgestomet and norgestomet followed by pregnant mare's serum gonadotropin. Journal of Animal Science, Champaign, v. 76, n. 9, p. 2235-2238, 1998.

CAVALCANTI, A. S.; BRANDÃO, F. Z.; NOGUEIRA, L. A. G.; FONSECA, J. F. Effects of GnRH administration on ovulation and fertility in ewes subjected to estrous synchronization. Revista Brasileira de Zootecnia, Viçosa, MG, v. 41, n. 6, p. 1412-1418, 2012.

Cline, M. A.; RALSTON, J. N.; SEALS, R. C.; LEWIS, G. S. Intervals from norgestomet withdrawal and injection of equine chorionic gonadotropin or P. G. 600 to estrus and ovulation in ewes. Journal of Animal Science, Champaign, v. 79, n. 3, p. 589-594, 2001.

DOWNING, J. A.; JOSS, J.; SCARAMUZZI, R. J. Ovulation rate and the concentrations of gonadotrophins and metabolic hormones in ewes infused with glucose during the late luteal phase of the oestrous cycle. Journal of Endocrinology, Bristol, v. 146, n. 3, p. 403-410, 1995.

EVANS, A. C. O. Ovarian follicle growth and consequences for fertility in sheep. Animal Reproduction Science, Manchester, v. 78, n. 3-4, p. 289-306, 2003.

FINDLAY, J. K.; CUMMING, I. A. FSH in the ewe: effects of season, live weight and plane of nutrition on plasma FSH and ovulation rate. Biology of Reproduction, Madison, v. 15, n. 3, p. 335-342, 1976.

FONSECA, J. F.; BRUSCHI, J. H. Reprodução assistida em pequenos ruminantes. Revista de Ciências Agrárias, Belém, v. 43, n. 1, p. 1-15, 2005.

FORTUNE, J. E.; RIVERA, G. M.; YANG, M. Y. Follicular development: the role of follicular microenvironment in selection of the dominant follicle. Animal Reproduction Science, Manchester, v. 82-83, n. 1, p. 109-126, 2004.

GINTHER, O. J.; KOT, K.; WILTBANK, M. C. Associations between emergence of follicular waves and flutuations in FSH concentrations during the estrus cycle in ewes. Theriogenology, Stoneham, v. 43, n. 3, p. 689703, 1995. 
INSTITUTO BRASILEIRO DE GEOGRAFIA E ESTATÍSTICA - IBGE. Produção da Pecuária Municipal 2012. Rio de Janeiro: IBGE, 2012. v. 40, p. 1-71. Disponível em: <http://www.ibge.gov.br/ home/estatistica/economia/ppm/2012>. Acesso em: 01 ago.2013.

KNIGHT, T. W. Effects of diet and liveweight on ovulation rates in Romney ewes. In: THE NEW ZEALAND SOCIETY OF ANIMAL PRODUCTION, 4., 1980, Dunedin. Proceedings... Dunedin: New Zealand Society of Animal Production, 1980. v. 4, p. 38-42.

MUÑOZ-GUTIÉRREZ, M.; BLACHE, D.; MARTIN, G. B.; SCARAMUZZI, R. J. Ovarian follicular expression of mRNA encoding the type 1 insulin like growth factor receptor (IGF-IR) and insulin like growth factor binding protein 2 (IGFBP2) in anoestrous sheep after 5 days of glucose, glucosamine or supplementary feeding with lupin grain. Reproduction, Bristol, v. 128, n. 6, p. 747756, 2004.

MUÑOZ-GUTIÉRREZ, M.; FINDLAY, P. A.; ADAM, C. L.; WAX, G.; CAMPBELL, B. K.; KENDALL, N. R.; KHALID, M.; FORSBERG, M.; SCARAMUZZI, R. J. The ovarian expression of mRNAs for aromatase, IGF-I receptor, IGF-binding protein-2, -4 and -5 , leptin and leptin receptor in cycling ewes after three days of leptin infusion. Reproduction, Bristol, v. 130, n. 6, p. 869-881, 2005.

NATIONAL RESEARCH COUNCIL - NRC. Nutrient requirements of dairy cattle. 6. ed. Washington, DC: National Academy Press, 2007

OLDHAM, C. M.; LINDSAY, D. R. The minimum period of intake of lupin grain required by ewes to increase their ovulation rate when grazing dry summer pasture. In: LINDSAY, D. R.; PEARCE, D. T. (Ed.). Reproduction in sheep. Canberra: Academy of Science Australian Wool Corporation, 1984. p. 274-276.

PINNA, A. E.; BRANDÃO, F. Z.; CAVALCANTI, A. S.; BORGES, A. M.; SOUZA, J. M. G.; FONSECA, J. F. Reproductive parameters of Santa Inês ewes submitted to short-term treatment with re-used progesterone devices. Arquivo Brasileiro de Medicina Veterinária e Zootecnia, Belo Horizonte, v. 64, n. 2, p. 333-340, 2012.

RABIEE, A. R.; LEAN, I. J.; GOODEN, J. M.; MILLER, B. G. Short-term studies of ovarian metabolism in the ewe. Animal Reproduction Science, Manchester, v. 47, n. 1, p. 43-58, 1997.

RADFORD, H. M.; DONEGAN, S.; SCARAMUZZI, R. J. The effect of supplementation with lupin grain on ovulation rate and plasma gonadotrophin levels in adult merino ewes. In:AUSTRALIAN SOCIETY OF ANIMAL
PRODUCTION, 13., 1980, Perth. Proceedings... Perth: Animal Production in Australia, 1980. v. 13, p. 457.

ROBINSON, J. J.; ROOKE, J. A.; MCEVOY, T. G. Nutrition for conception and pregnancy. In: FREER, M.; DOVE, H. (Ed.). Sheep nutrition. Canberra: CABI Publishing, 2002. p. 189-211.

SAMPAIO, M. C.; CARVALHO, A. B.; VARANDAS, F. R.; KLACZKO, L. B. An experimental demonstration of fisher's principle: evolution of sexual proportion by natural selection. Genetics, Bethesda, v. 148, n. 2, p. 719731, 1998.

SAUNDERS, G. A.; ALVES, N. G.; PÉREZ, J. R. O.; SOUZA, J. C.; MUNIZ, J. A.; JOSE NETO, A. Efeito da sobrealimentação com fontes de proteína de diferentes degradabilidades sobre a ovulação em ovelhas Santa Inês. Revista Brasileira de Zootecnia, Viçosa, MG, v. 39, n. 12, p. 2731-2738, 2010.

SCARAMUZZI, R. J.; CAMPBELL, B. K.; DOWNING, J. A.; KENDALL, N. R.; KHALID, M.; MUÑOZGUTIÉRREZ, M.; SOMCHIT, A. A review of the effects of supplementary nutrition in the ewe on the concentrations of reproductive and metabolic hormones and the mechanisms that regulate folliculogenesis and ovulation rate. Reproduction Nutrition and Development, Les Ulis, v. 46, n. 4, p. 339-354, 2006.

SCARAMUZZI, R. J.; OUJAGIR, L.; MENASSOL, J. B.; FRERET, S.; PIEZEL, A.; BROWN, H. M.; COGNIÉ, J.; FABRE NYS, C. The pattern of LH secretion and the ovarian response to the 'ram effect' in the anoestrous ewe is influenced by body condition but not by short-term nutritional supplementation. Reproduction, Fertility and Development, Camberra, v. 26, n. 8, p. 1154-1165, 2014.

SELAIVE-VILLARROEL， A. B.; CAVALCANTI NETO, C. C.; FREITAS, V. J. F. Efeito do flushing com feno de leucena (Laucaena leucocephal (Lam) de Wit) na taxa de ovulação de ovelhas deslanadas sem raça definida-SRD. Revista Brasileira de Reprodução Animal, Belo Horizonte, v. 26, n. 2, p. 112-114, 2002.

SIMPLÍCIO, A. A. Caprinocultura e ovinocultura de corte no Brasil: pontos para reflexão. Revista $C F M V$, Brasília, v. 17, n. 52, p. 26-36, 2011.

SMITH, A. J.; STEWART, R. D. Effects of nutrition on the ovulation rate of ewes. In: OLDHAM, C. M.; MARTIN, G. B.; PURVIS, I. W. (Ed.). Reproductive physiology of Merino shee: concepts and consequences. Perth: School of Agriculture (Animal Science) The University of Western Australia; 1990. p. 85-101. 
SOUZA, M. I. L. Indução e sincronização de estro em ovelhas: desafios e potencial. Revista Brasileira de Reprodução Animal, Belo Horizonte, v. 37, n. 2, p. 220 225, 2013.

STEWART, R.; OLDHAM, C. M. Feeding lupins to ewes for four days during the luteal phase can increase ovulation rate. Proceedings of the Australian Society of Animal Production, Camberra, v. 16, n. 1, p. 367-370, 1986.

VIDAL, M. F.; SILVA, R. G.; NEIVA, J. N. M.; CÂNDIDO, M. J. D.; SILVA, D. S.; PEIXOTO, M. J. A. Análise econômica da produção de ovinos em lotação rotativa em pastagem de capim Tanzânia (Panicum maximum (Jacq)). Revista de Economia e Sociologia Rural, Brasília, v. 44, n. 4, p. 801-818, 2006.

VIÑOLES, C. Effect of nutrition on follicle development and ovulation rate in the ewe. 2003. Thesis $(\mathrm{PhD}$ in Veterinary Medicine) - Faculty of Veterinary Medicine, Uppsala. Available at: <http://pub.epsilon.slu.se/410>. Accessed at: 01 ago. 013.
VIÑOLES, C.; FORSERG, M.; MARTIN, G. B.; CAJARVILlE, C.; REPETTO, J.; MEIKLE, A. Shortterm nutritional supplementation of ewes in low body condition affects follicle development due to an increase in glucose and metabolic hormones. Reproduction, Bristol, v. 129, n. 3, p. 299-309, 2005.

VIÑOLES, C.; MEIKLEB, A.; MARTINA, G. B. Shortterm nutritional treatments grazing legumes or feeding concentrates increase prolificacy in Corriedale ewes. Animal Reproduction Science, Manchester, v. 113, n. 1, p. 82-92, 2009.

WILLIAMS, S. A.; BLACHE, D.; MARTIN, G. B.; FOOT, R.; BLACKBERRY, M. A.; SCARAMUZZI, R. J. Effect of nutritional supplementation on quantities of glucose transporters 1 and 4 in sheep granulosa and theca cells. Reproduction, Bristol, v. 122, n. 6, p. 947956, 2001. 